\title{
Methodological Dilemmas: Researching Violent Young Men in Medellín, Colombia
}

\author{
Adam Baird
}

\begin{abstract}
This article highlights the main methodological problems and solutions encountered while researching violent young men in the marginalised north-eastern area of Medellín, Colombia. Using ethnographic methods, the research investigated how violent behaviour may be inherited, and its relationship to masculinities and youth. It asked how violence is transmitted to young men in both domestic and social spaces, and evaluated the relationship between marginalisation and social violence. Little has been written about how researchers can access violent actors who are reluctant to come forward or tell the truth, nor the ethical issues that arise when researching violent subjects in conflict contexts. This article explains how dangers were dealt with, but also how problems of accessing violent actors were overcome, and considers the ethical dilemmas.
\end{abstract}

\begin{abstract}
1 Introduction
This article highlights the main methodological problems and solutions encountered while researching violent young men (16-29 years old) in the marginalised north-eastern area of Medellín, Colombia, in 2008. The research was part of my PhD. I undertook it as a sole researcher using 25 life history interviews, principally with paramilitaries who dominated the selected neighbourhood, to investigate how violent behaviour may be inherited, and its relationship to masculinities and youth. A second contrasting group of youths - who participated actively in a community development organisation - were also interviewed to provide an understanding of why youths from the same socioeconomic background take markedly different paths in life. The methodological issues arising from researching that group will not be considered in this article, which focuses on the particular challenges faced when researching violent subjects. The research questions and key findings set out below aim to help the reader frame the methodological challenges explored here, in terms of the research objectives.
\end{abstract}

The key research questions were:
- If young men are vectors of most social violence, how does the transmission of violence to young men occur in both domestic and social spaces? How is this related to masculinities?

- Is there is a relationship between marginalisation and social violence? Why do some marginalised young men opt for violence while others in the same context do not?

- What does this tell us about the possibilities of interrupting the transmission of violence and promoting agency among young men, which can lead to community development?

Although at the time of writing, data analysis was still ongoing, key findings have already emerged. First, marginalisation and chronic social violence make young men in particular vulnerable to engaging in social violence. Among the youths working in community development, resistance to the use of violence was generated by their strong moral rejection of violent groups. This moral rejection tended to be initiated domestically by one influential older member of the family - normally a parent or grandparent in their early teenage years, but crucially was consolidated and reinforced as they grew older 
within the socialisation space of the youth development organisation where they participated. The combination of these domestic and social factors supported their participation in community development activities and the pursuit of licit forms of livelihood, despite extremely limited options in a marginalised and violent context.

Second, violent young men tended to have in common the absence of any significant male figure in their domestic sphere who promoted moral rejection of violence as they grew up, as the family was either unwilling or unable to provide one. These young men were more vulnerable to falling under the influence of older male youths or men involved with an armed group in their social world. Joining such groups was often perceived as an opportunity and a source of status. The absence of significant moral rejection of violence was manifest particularly through family dysfunction - which in turn was often linked to marginalisation - and the presence of family members or family friends already participating in armed groups. Violent youth often cited the genuine absence of licit opportunities of work and education as the reason for joining armed actors, and while their counterparts in the community development organisation faced the same difficulties, violent youth had markedly less domestic support in pursuing licit options.

Medellín has been blighted by a recent history of intense urban violence which peaked between 1989 and 1993 with an average of 5,385 homicides per year, in a city which at the time had just 1.6 million people (Arias et al. 1994: 29-30). In 1991, the figure reached an incredible 381 homicides per 100,000 of the population (Alcaldía de Medellín 2008: 6). Poor neighbourhoods were the worst affected, and young men were the majority of the victims and victimisers. From 1986 to 1993, 93.5 per cent of homicide victims were men and 68.7 per cent of all victims were between the ages of 13 and 30 years old (Arias et al. 1994: 30-1). These statistics remained largely unchanged from 1990 to 2002 (Suárez Rodríguez et al. 2005: 3). This violence was due to a combination of fighting between milicias - left-wing urban guerrillas or established street gangs - and, later, right-wing paramilitary forces (Medina Franco 2006; Rozema 2008). The urban milicias, linked to the rural guerrillas of the broader Colombian conflict, emerged significantly in Medellín in the mid-1980s, starting turf wars with local gangs which were often linked to drug trafficking cartels. In the mid-1990s, paramilitary groups, traditionally supported by state security forces, entered into the poor neighbourhoods exterminating the milicias and forming strategic alliances with gangs and drug-traffickers. In recent years, as paramilitary groups came to dominate the poor neighbourhoods of the city, open warfare subsided. This, combined with a controversial paramilitary demobilisation process that began in 2002, prompted a dramatic reduction in homicide rates to 28.6 per 100,000 by 2007 . However, drug trafficking and paramilitary activity remain worrying and homicide levels increased by 14 per cent in the first half of 2008 with 326 registered deaths. Fears still linger of a return to the violence of the 1990s (El Tiempo 2008).

\section{Entering dangerous spaces and generating safety mechanisms}

The issue of researcher and subject safety in dangerous environments is not foreign to methodological literature (Lee and Stanko 2003; Lee-Treneek and Linkogle 2000; Rodgers 2001). Yet little is written about how to access violent actors who are reluctant to come forward or tell the truth, nor about the ethical issues that arise when researching violent subjects in conflict contexts. This article does explain how dangers were dealt with, but also how problems of accessing violent actors were overcome, and considers the ethical issues faced when doing so.

Conducting the research in the marginalised north-eastern area of Medellín was dangerous, especially for the conspicuous foreigner, due to high levels of violence and crime. Researchers have been murdered in Latin America and must be particularly cautious in conflict zones or areas of high urban violence (Lee-Treneek and Linkogle 2000: 10). However, being 'streetwise' using common sense, local knowledge and language skills - reduced risks when travelling around poor neighbourhoods.

The more challenging issue was how to access violent paramilitaries within the neighbourhoods while staying safe. To stay safe, it was fundamental to use reliable gatekeepers to access paramilitaries and to understand their 
context. To gain this understanding, the researcher used participant observation at local community organisation Con-Vivamos ('Let's Live Together') and interviewed local leaders and community members. However, prior to participant observation, I spent five months interviewing academics and practitioners in Medellín who worked with youth and violence. While this was done principally to map out the history of youth and violence work in Medellin, it also laid the foundation for understanding the context of youth violence and hence strengthened my capacity to keep myself safe.

Con-Vivamos was chosen as its members are entrenched in the local community and thus excellent informants on local realities. The north-eastern area of Medellín is an extremely densely populated area of steep mountainside with houses literally stacked on top of each other. Such proximate living conditions make for a very close-knit community - everybody appears to know everybody. For example, senior members of Con-Vivamos went to school with present-day paramilitaries and today their children share the same schools. The organisation maintained open dialogue with paramilitaries as part of its security strategy, which they termed bailándolos ('taking them for a dance'). This meant maintaining a certain level of communication with them to identify potential dangers coming their way, while maintaining a critical view of their activities, often denouncing them. Participant observation brought me into contact with paramilitaries to arrange interviews and gave me an understanding of their context. But at the same time, working within the community organisation acted as a security filter as experienced organisation members had become expert local security analysts.

While participant observation helped keep my finger on the pulse of the community, it was important to check and re-check frequently what was 'ok' and 'not ok' with members of the organisation. Over time, my capacity to understand the 'rules' of local violence developed. Danger slowly became less unpredictable. However, it is important to note that dangers can never be totally manageable. While some violence may be partially predictable, other violence is spontaneous and emotive, and even the most prudent researchers could always be unlucky (Jamieson 2000: 64).

\section{Contacting violent actors}

I frequently accompanied members of ConVivamos on walks around the neighbourhood to talk to local leaders. Occasionally there were chance meetings with paramilitaries. When this happened, interviews were arranged which normally took place in paramilitaries' houses or at Con-Vivamos' offices. On occasion, impromptu interviews would take place when walking through the neighbourhood, so the voice recorder always needed to be at hand.

However, it generally took much more time and effort to secure the interviews than I had foreseen. The subjects tended to appear only in the afternoon and evening due to the patterns of their social and criminal activities. A member of Con-Vivamos would often take me to the house where they knew a young paramilitary lived. If they were not at home, messages would be left to try and arrange a meeting. Occasionally after a short search of the neighbourhood they could be located in a nearby café or on a street corner. Whenever they were located, respecting 'informed consent' (ESRC 2005), they would be asked if they wished to take part in the research. Although most agreed in principle to an interview, most turned up late to the designated meeting place, occasionally under the influence of drugs or alcohol, and on numerous occasions they did not turn up at all. This meant I had to arrange a large number of provisional interviews to meet the research targets.

\section{Interpreting partial or misleading data and managing fear}

A clear understanding of the local context proved central to interpreting and understanding the interview responses of violent young men, which were often partial or misleading. Hence, a keen gasp of local realities to interpret such responses took on enhanced value for data interpretation.

Gaining informed consent, explaining confidentiality and asking permission to record the meetings were turned into forms of 'icebreaker'. Interviewees were asked to invent their own pseudonyms and given a list of jovial nicknames to prompt them, and a notebook was produced to demonstrate the illegibility of my handwriting to open up the possibility of voice recording the meetings. Only one interviewee from 25 refused to be recorded. 
Learning parlache (local slang) was vital in understanding the interviewees. It was used so heavily it was more akin to a dialect, and tellingly, almost all words referring to violence were in parlache. I worked particularly hard to learn parlache, the spectacle of which prompted laughter and a familiar atmosphere during interviews. The early parts of the interviews tended to be more tense so the more complex or delicate questions were held back until the latter stages. Often such questions were asked repeatedly in different ways, using language interviewees could understand, to tease out the required data. The quality of the data often depended on my skill to subtly cross-examine without creating a feeling of cross-examination within the subject.

At times I was nervous about potentially irritating a subject with a history of violence by asking personal questions. This was more acute when the subject himself seemed tense. This occurred in one impromptu interview with a notorious sicario (assassin) who was edgy and aggressive. Where such tensions arose they diminished the quality of data obtained. Researcher nerves, whether rational or not, are not uncommon when researching violent actors or in violent contexts (Westerland 2000). To help manage fear it was useful for me to remember that the subjects had come voluntarily to the meetings and had been contacted through a trusted community organisation. When potential subjects felt I was a threat, they would simply refuse interviews and in such cases were left alone. I did experiment with 'snowballing' to contact violent young men.

Although it produced good data, I felt more at risk because of being pulled into less familiar contexts with subjects unknown by the accompanying community organisation. However, while ethnographic research in violent contexts is risky, it also establishes the context for evaluating danger (Peterson 2000), which positively informed the research.

But how much risk should researchers take to obtain their data? When I was in the field I acted within the boundaries of what I perceived as 'too risky'. But this often left a sense of dissatisfaction, and led to me wondering 'What if I'd have pushed a little harder or been a bit more risky, how much better could my data have been?' However, while researching in violent contexts is frustrating at times, I would posit that it is the researcher's responsibility to err on the side of caution when in doubt.

Despite the candour of some paramilitaries about certain parts of their lives, they often used vague language around acts of violence they had committed rather than talking about them explicitly. Terms such as la vuelta (the rounds) were used which can mean anything from collecting extortion money, to selling drugs or killing people. The researcher had to listen carefully to the story to understand what la vuelta actually entailed. Due to a number of factors such as trust, shame, fear, political motivations and their legal and security concerns, paramilitaries would often spin or lie about issues around violence and criminal activity. But as the interviews progressed, less incongruous, more confessional data would emerge to complete a previously mentioned story. This meant that data had to be pieced together after the interview to build up a more accurate version of events.

Again, understanding local context was crucial to filling in certain blanks, so arguably, effective data interpretation in this context would not be possible using less ethnographic methodologies.

\section{Ethics and building rapport with criminal and violent subjects}

Hallowell et al. (2005: 149) comment that it is the way that we relate to and treat others that makes our research ethical. But how should the researcher relate to a criminal and violent subject? Building rapport with research subjects improved my data collection, but how ethical is it to build rapport with a victimiser? How close is too close? These questions posed a dilemma for which no course of action seemed entirely satisfactory (De Laine 2000: 3). In this case I felt it was possible to build rapport with the subjects, while at the same time not getting 'too close' such as turning down invitations to go out drinking - and by maintaining a critical view of their criminal and violent activity.

To obtain good quality data in the interviews, it was necessary to use friendliness, humour, 'good listening' and genuine efforts to empathise with their circumstances to understand the subjects. Without exception, each interviewee had been a victim of violence and marginalisation at some stage in their lives. They were all part victim, part victimiser. Some interviewees were met 
more than once around the neighbourhood and friendly language and closer ties were built. This arose from chance meetings in the street and the process of chatting with a given paramilitary more than once when trying to schedule an interview. A handful were interviewed twice and there appeared to be more rapport in the second interview. Had I the time and capacity, a series of interviews with each subject, rather than just one with each, would have ameliorated the data quality. However, as paramilitaries proved particularly hard to pin down for even just one interview, I quickly realised that it would be unwise to opt for a 'half now, half later' interview strategy as the 'half later' may never have materialised.

Unsurprisingly, the subjects frequently emphasised their own victimisation and underplayed their acts that victimised others. Therefore it was important not to fall into a type of Stockholm Syndrome, or develop over-rapport which distorts the researcher's perception of the subjects (Peterson 2000; De Laine 2000).

\section{Conclusion: ethnography and immersion in context}

As the above experience suggests, ethnographic methodology via participant observation provided close contextual understanding that was essential to safety, accessing violent interviewees and crucially, interpreting the interview data. By immersing myself in the community, its politics, realities and relations I was given a close-up insight into the context of my research. This was facilitated by the trust and friendship that I built with my colleagues and other members of the local community. The researcher will often find in contexts of ongoing violence that there is a general fear to speak out against its perpetrators, which presents a significant obstacle to accessing data. In marginalised north-eastern Medellín, community members do not want to speak out against paramilitary activity for fear of reprisals. Only when I had gained the confidence of local community leaders by meeting them a number of times did they begin to open up to me about what they really thought.

Even at Con-Vivamos, the organisation where I conducted my participant observation, it took a month or so before I felt I had established good relationships with two colleagues. At times, I felt that my colleagues at Con-Vivamos were testing me: Were my political beliefs similar to theirs? How committed was I to social change? Essentially, they were testing to what extent was I one of them and could be trusted? Notably, candour about sensitive community issues - such as how paramilitaries were influencing local politics, or who was suspected to be behind the most recent murder - did not initially emerge from the more official meetings I held. Instead they came from informal spaces: at lunch, when going on walks through the community with a member of Con-Vivamos, over a beer and a kebab, or at some point on a night out. Socialising with my colleagues, including taking part in football matches and community events, was key to my acceptance and trust building. I made genuine friends at Con-Vivamos, and as friends, we confided in each other. Upon reflection some of the most fruitful insights during my research were dependent on the relationships that I had established with others in the field. The ethnographic methodology used laid the foundations for those relationships.

\section{References}

Alcaldía de Medellín (2008) Final Document Analysis - Disarmament Plan 2004-2008, Medellín, Colombia, Alcaldía de Medellín

Arias Orozco, Edgar; Medina Franco, Gilberto and Bonilla Naranjo, Wilson (1994) Juventud de Medellín: Pasados Ausentes, Presentes Intensos [Medellin's Youth: Absent Pasts, Present Intensities], Medellín: Instituto Popular de Capacitación

De Laine, Marlene (2000) Fieldwork, Participation and Practice: Ethics and Dilemmas in Qualitative Research, London: Sage

El Tiempo (18 July 2008) 'Homicidios en Medellín Crecieron 14 por Ciento' ['Homicides in Medellín Rose by 14 Per Cent']

ESRC (2005) Research Ethics Framework, Economic and Social Research Council, www.esrcsocietytoday.ac.uk/ESRGInfoCentre/ opportunities/research_ethics_framework (accessed 19 August 2008)

Hallowell, Nina; Lawton, Julia and Gregory, Susan (2005) Reflections on Research: The Realities of Doing Research in the Social Sciences, Maidenhead: Open University Press 
Jamieson, Janet (2000) 'Negotiating Danger in Fieldwork on Crime', in Geraldine LeeTreneek and Stephanie Linkogle (eds), Danger in the Field: Risk and Ethics in Social Research, London: Routledge

Lee, Raymond M. and Stanko, Elizabeth A. (2003) Researching Violence: Essays on Methodology and Measurement, London: Routledge

Lee-Treneek, Geraldine and Linkogle, Stephanie (2000) 'Putting Danger in the Frame', in Geraldine Lee-Treneek and Stephanie Linkogle (eds), Danger in the Field: Risk and Ethics in Social Research, London: Routledge Medina Franco, Gilberto (2006) Historia Sin Fin...: Las Milicias en Medellín en la Década del Noventa [Never-ending Story.... The Militia in Medellin in the 1990s], Medellín, Colombia: Instituto Popular de Capacitación

Peterson, J. (2000) 'Sheer Foolishness: Shifting Definitions of Danger in Conducting and Teaching Ethnographic Field Research', in Geraldine Lee-Treneek and Stephanie Linkogle (eds), Danger in the Field: Risk and Ethics in Social Research, London: Routledge
Rodgers, D. (2001) Making Danger a Calling: Anthropology, Violence and the Dilemmas of Participant Observation, Working Paper 6, Grisis States Research Centre, London: London School of Economics

Rozema, Ralph (2008) 'Urban DDR-processes: Paramilitaries and Criminal Networks in Medellín, Colombia', Journal of Latin American Studies 40: 423-52

Suárez Rodríguez, Clara; Giraldo Giraldo, Carlos; García García, Hector; López López, Maria; Cardona Acevedo, Marlene; Corcho Mejía, Carolina and Posada Rendón, Carlos (2005) 'Escenarios de Homicidios, 199'0-2'002' ['Homicide Scenes, 1990-2002'], Estudios Poíticos 26: 185-205

Westerland, Louise (2000) 'Taking the Flack: Operational Policing, Fear and Violence', in Geraldine Lee-Treneek and Stephanie Linkogle (eds), Danger in the Field: Risk and Ethics in Social Research, London: Routledge 